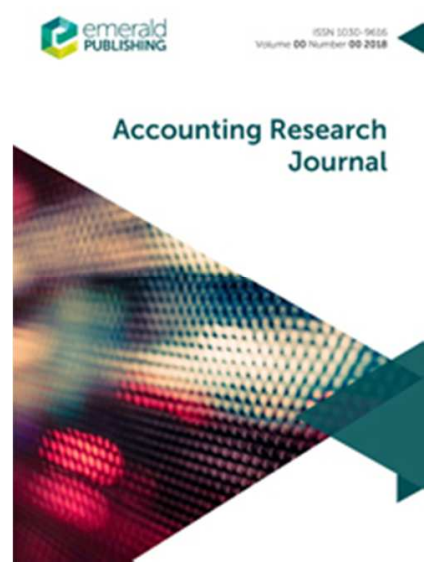

The Long-Term Effect of Economic Value Added Adoption on the Firm's Business Decision

\begin{tabular}{|r|l|}
\hline Journal: & Accounting Research Journal \\
\hline Manuscript ID & ARJ-01-2018-0018.R1 \\
\hline Manuscript Type: & Article \\
\hline Keywords: & economic value added, residual income, business decision \\
\hline \multicolumn{2}{|c}{} \\
\hline
\end{tabular}

SCHOLARONE ${ }^{m}$

Manuscripts 


\title{
The Long-Term Effect of Economic Value Added Adoption on the Firm's Business Decision
}

\begin{abstract}
We examine the long-term effects of adopting economic value added (EVA) as a compensation tool on managers' behaviour. We extend the sample used in prior studies both in the time and the cross section dimensions. Our conclusions are distinct from those offered by existing studies. We show that EVA adopters, relative to non-EVA adopters, increase the working capital cycle, use their assets less intensively, and decrease their payouts to shareholders via a decrease in dividends and share repurchases. In investing decisions, we find a decrease in new investments, but no change in asset dispositions after the adoption of EVA compensation plans. Our results highlight that the EVA adoption provides more incentives to reduce the total cost for capital rather than increasing operations and maximising shareholder wealth.
\end{abstract}

Keywords: economic value added; residual income; business decision. 


\section{The Long-Term Effect of Economic Value Added Adoption on the Firm's Business Decision}

\section{Introduction}

The agency problem has long been recognised as one of the major issues in management and finance. A rational manager maximises his own utility, and cares about the shareholders' interest only as long as his interest and theirs coincide. Thus, aligning those potentially conflicting interests has been subject to considerable debate.

The expected role of the executive manager is to maximize the firm's value (Wallace, 1997) and, hence, shareholder wealth. This maximisation is achieved through optimal management decisions; particularly investment, financing, and operating decisions. Traditionally, shareholders try to achieve this through managerial ownership. However, theoretical and empirical arguments show that share ownership can have both an alignment and entrenchment effects (Khan and Mather, 2013). The quality and independence of remuneration committees have also been argued to help align executive compensation with firm financial performance (Cybinski and Windsor, 2013; Gray and Nowland, in press).

One principle that has long been recognised is that, in order for a company to create value and to generate wealth, a firm must earn a rate greater than its cost of capital (Drucker, 1995). This is historically referred to as residual income (henceforth RI). One variant of RI is the economic value added (EVA) introduced by Stern Stewart \& Co., US-based consulting firm, in 1991 as an alternative performance measurement to traditional earnings and cash flows based metrics. EVA is similar to RI but includes additional adjustments to accounting values suggested by Stern Stewart (Stewart, 1991; Stern et al., 1995). However, EVA has been criticised as simply "re-labelling the resultant residual income concept" (O'Hanlon \& 
Peasnell, 1998, p.425). According to O'Hanlon and Peasnell (1998), the adjustments are based on consulting experiences that are not clearly underpinned by a theoretical framework. Although 120 aspects of conventional GAAP are identified to adjust the financial accounts for EVA, the basic adjustments include the capitalization of all intangible investments, such as goodwill and research and development expenditure, and general provision for bad debts and inventory obsolescence (Stewart, 1991; O’Hanlon \& Peasnell, 1998).

The economic value added (EVA) metric has received considerable attention in the literature as the best performance measure with the ability to align managers' interests with those of the shareholders (Wallace, 1997; Balachandran, 2006).

In a seminal paper, Wallace (1997) investigated whether the use of residual income bonus plans led to the making of decisions consistent with the economic incentives embedded in those plans. He concluded that, with regard to operating decisions, executive managers of a firm adopting the residual income method as a compensation metric will make decisions that would increase assets disposition and decrease new investments.

While our aim is similar, we extend Wallace's (1997) work in three distinct directions. First, we modify the statistical model to directly control for the firms that did not adopt EVA. Second, we extend the time horizon of study to cover the period from 1981 to 2012. More importantly, the number of sample firms is more than double that of Wallace (1997). Extending the sample in both the time and the cross section dimensions will remove doubt that previous results may have been due to data limitations. Third, we focus exclusively on EVA adopters, while Wallace (1997) uses a mixture of EVA and RI adopters. We therefore remove the possibility that results may be contaminated by the presence of RI adopters. Contrary to Wallace's (1997) findings, our paper argues that relative to non-EVA adopters, EVA adopters decrease their payouts to shareholders, increase the working capital cycle and 
use their assets less intensively. We also examine the firm's investment policies through asset dispositions and new investments. Our results confirm Wallace's (1997) finding that EVA adopters decreased their new investments after the adoption of an EVA performance measure. However, we find no relationship between asset dispositions and an EVA-based executive compensation plan. Overall, our research indicates that EVA adopters tend to utilise more net working capital, but are more reluctant to use free cash flows for dividend payouts, repurchases and capital expenditure relative to non-EVA adopters. As a result of our findings, we can say that following the adoption of EVA, the conflict of interest between shareholders and managers may take place again. This is more likely due to managers' own utility maximisation through incentive compensation plans rather than shareholders' value by reducing share repurchases and dividend payouts.

The structure of the paper is as follows. Section 2 offers a review of the existing literature. Section 3 describes the data sources, sample selection, and variable definitions. Section 4 describes the methodology, and Section 5 discusses the empirical results. The final section summarises the results and offers some concluding remarks.

\section{Literature Review}

The vast majority of the existing research has examined whether the adoption of EVA incentive compensation plan has any impact on managers' investment behaviour (Wallace, 1997; Kleiman, 1999; Balachandran, 2006). All of this empirical research has the common assumption that the adoption of the EVA compensation system will rationalize a firm's investment decision and will lead to it using the existing assets more efficiently to generate more residual income and, hence, to maximize shareholders' wealth as well. 
One major strand in the EVA literature focuses on the usefulness of EVA in explaining the variation of stock price performance. Biddle et al. (1997) find that EVA actually has poorer explanatory power of US stock return than other simpler performance metrics. Worthington and West (2004), in their study of Australian firms, reached different conclusions, arguing that the divergence may be at least partly explained by the difference between the US and Australian accounting systems.

In this paper, we focus on manager and firm behaviour as a result of adopting EVA as a reward system. Pham et al. (2011) investigated the impact of EVA on firms' corporate governance using a sample of 136 Australian listed firms. Chiwamit et al. (2017) discussed the mediating role of regulators imposing EVA to support the privatisation of state-owned enterprises in Thailand. McLaren et al. (2016) presented a case study and discussed the reasons for the implementation, evolution and abandonment of EVA based on three firms in New Zealand. However, the most important study in this field is Wallace (1997). The study focuses on the firm's behaviour directly by looking at changes in a number of accounting fundamentals following the adoption of value added measures. Similar work has been carried out by Kleiman (1999) and Balachandran (2006). Wallace (1997) compared a group of forty companies adopting RI and EVA as compensation plans with the same number of carefully matched control firms. He examined the impact of the adoption of RI-based compensation on investing, finance and operating decisions within the three-year post-adoption period compared to the five-year pre-adoption period.

Kleiman (1999) extended the sample to 71 US firms adopting EVA as an incentive compensation system. One important finding is that firms monitor their working capital regardless of the compensation plan they adopt. Kleiman (1999) also fails to confirm some of Wallace's conclusions. Balachandran (2006) investigated whether switching from traditional 
accounting-based performance plans to an RI-based compensation incentive would affect the investment motive. His results show strong support for the view that RI-adopting firms do actually deliver higher RI after adoption. However, the results also show no significant change in investment pattern.

In their study of how managers perform under an EVA bonus scheme, Riceman et al. (2002), examine whether the managers who are compensated using EVA-based bonus plans outperform the managers who are compensated on traditional accounting-based bonus plans. This system, they claim, can change managerial behaviour at the firm level. Riceman et al. (2002) contend that 'one reason to expect better performance for managers on EVA bonus plans is that an EVA-based reward system better aligns the interests of the manager and the firm' (p.543).

Riceman et al. (2002) used a sample of 117 managers in major international New Zealand companies, focusing on whether the relationship between the compensation type and performance depends on the understanding of EVA. Their results show a positive and dramatic effect of EVA understanding on the performance of EVA-adopting managers. An important finding by Riceman et al. (2002) is that EVA understanding is not always high.

\section{Research Design and Methodology}

EVA is defined as the profit earned by the firm less the cost of financing the firm's capital. It is similar to RI but adjusted for net operating profit after tax (NOPAT) and invested capital where needed. It is also referred to as net operating profit less a charge for the opportunity cost of invested capital (Worthington \& West, 2001). 
Residual income (RI) is defined as follows (Biddle et al., 1997):

$$
\mathrm{RI}=\mathrm{NOPAT}-\left(I C_{t-1} \times \mathrm{WACC}\right)
$$

where NOPAT is net operating profit after tax, $I C_{t-1}$ is lagged book value of net assets, and WACC is the company's weighted average cost of capital. This basic formula in fact represents the value created in excess of the required return to the company's shareholders. Economic value added (EVA) is obtained by making a number of adjustments to NOPAT and the invested capital (IC) (Stewart, 1991). Additional details on EVA components can be found in Worthington and West (2004).

\subsection{Data}

Our sample consists of US firms that have chosen to adopt the EVA compensation system. Consistent with Wallace (1997) and Kleiman (1999), the first year of the company announcing its adoption of EVA is defined as the event year. Since it can take several months for the company to fully adopt EVA, we follow standard practice and consider the month of December of that year as the event date $(t=0) .{ }^{1}$ We started initially with Wallace's (1997) 23 firms that adopted the EVA compensation plan. This list of adopter firms was then updated by Kleiman (1999) and the number of EVA adopter was increased to 71 firms. Then, we began our search using various databases where the EVA-implementing firms may be identified. These comprise the Stern Stewart \& Co. brochure, Lexis-Nexis, the Proxy Statement, the 10-Q report and the Wall Street Journal. The majority of firms which adopted

\footnotetext{
${ }^{1}$ This approach is also adopted by Wallace (1997), Kleiman (1999), and Balachandran (2006).
} 
EVA disclose such information in their official releases. For example, RR Donnelley \& Sons Co. states in its 10-Q report:

"Over the past three years, the company has adopted the principles of Economic Value Added (EVA) as its primary financial framework. The objective of this system is to put in place a system of value-based metrics that measures periodic progress toward improved shareholder value creation. To enhance value ...

Over time, the application of the EVA financial framework to the company's decision-making process is likely to produce slower revenue growth, enhanced free cash flow, a stronger competitive position and improved return on invested capital ${ }^{, 2}$.

We identify an initial list of 101 firms adopting EVA in the period 1987-2001; these represent different US market sectors. A total of 12 EVA adopters were then excluded from the sample because of the unavailability of price/return information and accounting data, leaving a final sample of 89 EVA adopters on NASDAQ, NYSE and American Stock Exchange Markets.

Table 1 shows the pattern of EVA adoption and reveals that most EVA adoption took place in the period 1993-1997. The frequency of adoption increased up to 1996 and then started decreasing afterwards. This decline may be indicative of market saturation in the demand for EVA-based compensation contracts. Table A1 in the appendix provides the full list of EVAadopting firms, the year of adoption, the matching control firms and the SIC codes of these firms respectively.

\section{[Table 1 about here]}

\footnotetext{
${ }^{2}$ Source: United States Securities and Exchange Commission, Washington, D.C. 2059. RR Donnelley \& Sons Co, FORM 10-Q, May 7th 1997.
} 
Financial and accounting data on these firms were then collected from the Centre for Research in Security Prices (CRSP) and COMPUSTAT databases. The firm data used in this paper were extracted from balance sheets, income statements and cash flow statements. The dependent variables are similar to those of Wallace (1997) and are defined as follows:

- Dispositions: sale of plant, property and equipment (SPPE). ${ }^{3}$

- New investment: acquisitions (AQC) plus capital expenditures (CAPX).

- Repurchases per share: repurchases of common stock (PRSTKCC) divided by common shares outstanding (CSHO).

- Dividends per share: dividend available to common shareholders (DVC) divided by common shares outstanding (CSHO).

- $\quad$ Assets turnover: revenue (REVT) divided by average total assets (TA).

- Inventory turnover: cost of goods sold (COGS) divided by average inventory (INVT).

- Accounts receivable turnover: revenue (REVT) divided by average accounts receivable (AR).

- Accounts payable turnover: cost of goods sold (COGS) divided by average accounts payable (AP).

- $\Delta$ Leverage: changes in debt for firms between periods to total assets

In order to control for the size effects through the analysis process all the dependent variables of this research are deflated by the initial total assets (TA) and used in levels rather than differences.

\subsection{Model considerations}

\footnotetext{
${ }^{3}$ Abbreviation between brackets stands for COMPUSTAT Mnemonic.
} 
Empirical results are sensitive to the choice of the econometric model and variable measurement. In an event study, where the interest lies in assessing the impact of a particular event (in our case, the event is the adoption of EVA), three critical questions need to be answered: (i) How do we measure abnormal performance? (ii) What metric should we use for the empirical model? (iii) What is the appropriate statistical model?

Assessing abnormal performance is tricky, and care should be taken in adopting definitions of abnormal performance that avoid misspecification. Wallace (1997) and Balachandran (2006), for example, define abnormal performance as the difference of an accounting variable before and after adoption. This implicitly uses the firm as its own benchmark or control firm. However, this would lead to the omission of relevant firm, market or industry effects, and this in turn can confound the interpretation of empirical results. Barber and Lyon (1997) favour the use of control firms in calculating abnormal performance. The use of a control firm alleviates the problems of the misspecification because a similar firm provides good proxies for the firm, industry and market effects. Although Wallace (1997) does use control firms, he does not contrast them with the treatment (or adopter) firms. Instead, he uses the control firms alongside the treatment firms. Below, we rectify this shortcoming by modifying Wallace's model to contrast each treatment firm with its own control firm.

Control firms as selected similar to Wallace (1997). We first determine the Standard Industrial Classification (SIC) code of adopter companies using the CRSP and COMPUSTAT databases. We then select a sample of the best matched control firms that closely resemble the adopter firm. The selection processes for control firms are based on the following criteria:

1. Same industry sector: the sample firm should have the same 4-digits SIC code. If not, we chose the best matched firm with 3-digits SIC code. 
2. Same firm size: we use total assets and number of outstanding common shares in the year prior to the year of adoption to match adopters and control firms.

3. Data availability: the control firm should have sufficient annual data to match that of the adopting firm.

4. Crosscheck: once the above conditions have been met, we check Lexis-Nexis, the Proxy Statement, the 10-Q report and the Wall Street Journal to ensure that the firm in question has not adopted EVA or RI compensation scheme. Otherwise, we select the next available firm.

The second question relating to the choice of metric for the empirical model is more controversial. Various papers have analyzed the conceptual advantages and disadvantages of price and return models. Gonedes and Dopuch (1974) claim that return models theoretically outperform price models in the absence of well-developed theories of valuation. Lev and Ohlson (1982) consider the two methods as complementary, whereas Landsman and Magliolo (1988) argue that for specific applications price models are superior to return models. Christie (1987) concludes that while return and price models are economically the same, return models are econometrically less problematic.

The empirical results of Kothari and Zimmerman (1995) confirm that the earnings' response coefficients of the price models are less biased. However, return models have less serious econometric difficulties than price models. In some research contexts the combined use of both price and return models may be useful and seems to be the best course of action to take.

In our context, the question is whether we should use levels or differences of financial variables. In principle, the empirical model should reflect an underlying true or theoretical model. If a model or a hypothesis predicts an effect on value (price; level) then the most logical conclusion would be to model value as a dependent variable rather than growth 
(return; difference). While sometimes statistical considerations such as stationarity make it impossible to model levels directly, this is usually true for time series regressions and not cross sectional regressions. Thus, we contend that whenever there are no statistical impediments, an empirical model should reflect the basic theoretical models or hypothesis. Below, we argue that a model in levels better reflects the basic hypothesis and produces more robust statistical results.

The third question on the appropriate statistical model is also important in that it helps us avoid spurious results. We do not wish to find 'significant' effects when in fact there are none, and vice versa. Thus, it is important that the empirical model is properly specified. Apart from the variables of interest (the dependent and independent variables), the model should also include other relevant control variables. Ignoring these control variables biases estimation results and may lead to spurious statistical conclusions. One important modification to Wallace's model we propose is to replace the change in stock ownership of the top management and board of directors by a stock market return index. We argue that the former is an endogenous variable and is therefore correlated with the error term, which biases the estimated coefficients. We also use an alternative specification that uses abnormal measures of both dependent and independent variables.

To address the above questions, we start from Wallace (1997) as a base model. Wallace (1997) used a sample of 40 firms that adopted RI-based compensation plans to test whether the adoption of the RI metric would influence the action of these firms compared to the action of other selected firms using traditional accounting-based compensation plans. His approach is therefore based on contrasting the adopters, which he calls the treatment firms, with the non-adopters, which he calls the control firms. The period of investigation extends to five years prior to the adoption, and up to three years following the adoption date (event date). 
In the next subsection, we present an alternative model that can more sensibly capture potential differences between adopters and non-adopters.

\subsection{An Alternative Model}

Wallace (1997) uses the difference in variables between the pre- and post-adoption years for all firms. To test for potential adoption effect, he runs the following regression

$$
\Delta \text { Dependent }_{i}=\alpha+\beta_{1} \text { Type }_{i}+\beta_{2} \Delta \text { Owner }_{i}+\beta_{3} \Delta \text { Leverage }_{i}+\varepsilon_{i}
$$

where $\Delta$ refers to the difference between the average of a particular variable before the adoption date and the average of the same variables after (and including) the adoption year, and the index $i$ refers to both treatment and control firms. $\Delta$ Dependent $_{i}$ is the change in the variable of interest (e.g., share repurchases and residual income) for firm i between periods. Type $_{i}$ is an indicator variable that is set equal to 1 for RI-based compensation adopting firms and 0 for non-adopting matching firms. Leverage $e_{i}$ is defined as debt divided by total assets

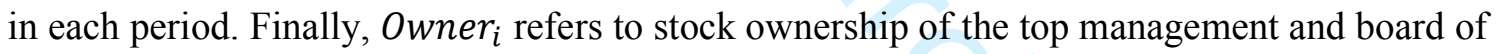
directors. Adoption of RI-based compensation is deemed to have an effect if $\beta_{1}$ is significantly different from zero (the average adopter and non-adopter have different means).

While the above regression appears to make sense its main drawback is the implicit assumption that both adopters and non-adopters have identical sensitivity to the control variables. For example, treatment firms may have a different sensitivity to leverage (for instance, because they have a different size) and thus their coefficient may be different from $\beta_{3}$. Thus, the above model is potentially misspecified and could consequently lead to a biased estimate of $\beta_{1}$. 
We propose an alternative model which directly contrasts the treatment and control firms' performances. Define the average abnormal performance $(A b n)$ in the post-adoption period as

$$
A b n P_{i}^{+}=\operatorname{Dep}_{i}^{+}-\text {Dep }_{i, \text { Control }}^{+}
$$

and the pre-adoption period as:

$$
A b n P_{i}^{-}=D e p_{i}^{-}-\text {Dep }- \text {, Control }
$$

the pre-adoption (post) period is referred to by superscripting variables with a minus (plus) sign. $D e p_{i}^{+/-}$is some performance or accounting variable for treatment firm $i$, whereas $D e p_{i, \text { Control }}^{+/-}$is the same variable for a matching firm for treatment firm $i$.

There are two main advantages to this approach. First, this specification allows both difference (return) and level (price) measures. The reason for this advantage is that what matters here is the difference between a treatment firm and a matching firm. Assuming the control firm is a perfect match, then the difference before the event $\left(A b n P_{i}^{-}\right)$should be close to zero, while the difference after the event $\left(A b n P_{i}^{+}\right)$should be different from zero under the hypothesis that the event has a significant effect.

The second advantage is more important. For less than perfect control firms, there are differences in performance both before and after. For example, if the closest matching firm to a given treatment firm is half its size, we would expect, for example, its value to be roughly half. So the abnormal measure before adoption $\left(A b n P_{i}^{-}\right)$should be positive. However, adoption effect can still be identified, because in the absence of any effect, there should be no difference between $A b n P_{i}^{-}$and $A b n P_{i}^{+}$regardless of whether each of them is different from zero.

The basic model that captures the adoption effect is given by 


$$
A b n P_{i}^{+}=\alpha+\beta_{1} A b n P_{i}^{-}+\varepsilon_{i}
$$

The parameter of interest is $\beta_{1}$, and the null hypothesis of no effect is $H_{0}: \beta_{1}=1$ (i.e. the difference between treatment and control firm is unchanged).

Since abnormal performance could also be the result of changes in other firm characteristics, we need additional control variables to improve the specification of the regression model.

We use total assets and debt as control variables. Define abnormal assets and abnormal debt as the difference between the assets and debts between the treatment and control firms, respectively. That is,

$$
\operatorname{AbnT} A_{i}^{+}=T A_{i}^{+}-T A_{i, \text { Control }}^{+}
$$

and

$$
A b n D e b t_{i}^{+}=D e b t_{i}^{+}-D_{e b t_{i, \text { Control }}^{+}}
$$

The full model is then given by

$$
A b n P_{i}^{+}=\alpha+\beta_{1} A b n P_{i}^{-}+\beta_{2} A b n T A_{i}^{+}+\beta_{3} A b n D e b t_{i}^{+}+\varepsilon_{i}
$$

If there is no effect resulting from the adoption, then the abnormal performance before the event should be equal on average to the abnormal performance after the event. Any possible change in abnormal performance could be due to the control variables (abnormal TA and abnormal debt). Under the null hypothesis of no effect $\beta_{1}=1$. However, we can operationalize testing this hypothesis by subtracting $A b n P_{i}^{-}$from both sides of the equation to obtain

$$
A b n P_{i}^{+}-A b n P_{i}^{-}=\alpha+\delta_{1} A b n P_{i}^{-}+\beta_{2} A b n T A_{i}^{+}+\beta_{3} A b n D e b t_{i}^{+}+\varepsilon_{i}
$$

where $\delta_{1}=\beta_{1}-1$. Thus, testing $H_{0}: \beta_{1}=1$ is equivalent to testing $H_{0}: \delta_{1}=0$. 


\section{Empirical Results}

Table 2 presents summary statistics of the investigated potential investment decisions (the dependent and independent/control variables employed in model (2)). All dependent variables have been winsorised at the $99^{\text {th }}$ percentile to remove outliers. The mean values of disposition per share are \$26.191 million and \$21.596 million for firms adopting EVA-based compensation and control firms respectively. Reflecting overall expectations of negative disposition per share after EVA adoption, in particular standard deviation, for matching firms (control firms) is higher than the corresponding adopting firms. Interestingly, the mean new investment is $\$ 285.998$ million for adopting firms, whereas the mean new investment is \$251.002 million for matching firms, which indicates that adopting firms operate with a considerably greater balance of new investment. Both adopter firms and matched firms operate with considerable leverage levels, although adopters have, again, greater levels. Moreover, all dependent variables appear to have a highly right-skewed distribution, as indicated by the large standard deviations. Overall, except for inventory turnover, the average level of both dependent and independent variables is greater for our sample of adopting firms.

\section{[Table 2 about here]}

Table 3 shows the results obtained for two investing decisions. The models explain a fairly good proportion of variability in abnormal dispositions and abnormal new investments (the adjusted- $R^{2}$ are $34.01 \%$ and $51.04 \%$ respectively). As discussed earlier, $\delta_{1}$ the coefficient of lagged performance $\left(A b n P_{i}^{-}\right)$is the parameter of interest and we are testing for the null hypothesis that there is no effect $\left(H_{0}: \delta_{1}=0\right)$ of adoption on firm performance. The result shows that we fail to reject the null hypothesis for dispositions, so the adoption of EVA-based compensation, contrary to Wallace (1997), has not changed the disposition of assets. The 
growth or decline in abnormal dispositions is mostly explained by the differential size and differential leverage. In the first case, the coefficient of $A b n T A_{i}^{+}$equals 0.003 and is highly significant, implying that the increase (decrease) in dispositions is partly explained by the greater (smaller) size of the treatment firm relative to the control firm. On the other hand, more (less) leveraged firms have decreased (increased) their dispositions relative to nonadopters (the coefficient of $A b n D e b t_{i}^{+}$is -0.024 and significant at the $1 \%$ level).

On the other hand, we reject the null hypothesis that there are no effects of adoption on new investment decisions. The coefficient of lagged abnormal new investment, $\delta_{1}$ equals -0.679 and is highly significant at a p-value of less than 0.001 . This is clear evidence showing that abnormal new investment has decreased significantly after adoption. This result is much stronger statistically than Wallace's negative impact which is found to be weakly significant with a p-value of 0.09. Our results are also contrary to Balachandran (2006) and Kleiman (1999) who find no significant change in investment patterns. The control variables are also significant. First, like dispositions, abnormal size has a positive impact on new investments. This is expected since larger firms have greater ability to invest in absolute terms. However, unlike dispositions, abnormal leverage has a significant but positive coefficient. This implies that high leverage firms have a greater increase in new investments compared with lower leverage firms.

Table 4 shows the results for financing decision. The adjusted- $R^{2}$ is very high for dividends $(=75 \%)$ and reasonably high for repurchases $(=20.12 \%) .{ }^{4}$ Thus, the models explain a good proportion of variability in abnormal repurchases and abnormal dividends. The coefficient of lagged performance, $\delta_{1}$, is the parameter of interest. Contrary to Wallace (1997), the results show a fall in abnormal repurchases and dividends. The null hypotheses $\left(H_{o}: \delta_{1} \neq 0\right)$ for

\footnotetext{
${ }^{4}$ Wallace (1997) models exhibit very low adjusted- $R^{2}$. For example he finds an adjusted- $R^{2}$ of $8 \%$ for repurchases and a negative one for dividends.
} 
repurchases and dividends are strongly rejected; both coefficients (-0.591 and -0.568 respectively) are significant and negative, implying a reversal of the effect found in Wallace (1997). Thus, contrary to Wallace, our results suggest managers decrease share repurchases following adoption. Furthermore, while EVA-RI adoption has no effect on dividends in Wallace (1997), this study finds a strong and negative effect. This implies that managers of EVA adopted firms are reluctant to use free cash flows for both repurchases and dividend payouts relative to non-EVA adopters. There is no size or leverage effect as both control variables are insignificant in repurchases and dividends.

\section{[Table 3 about here]}

\section{[Table 4 about here]}

Table 5 shows the results for four operating decisions, namely asset turnover, inventory turnover, AR turnover and AP turnover. Three of the four estimated models explain a high proportion of variability in abnormal asset turnover, inventory turnover, and AP turnover (the adjusted- $R^{2}$ are $52.23 \%, 11.66 \%$, and $29.34 \%$ respectively). The AR turnover has a lower adjusted- $R^{2}(5.30 \%)$. As discussed earlier, $\delta_{1}$, the coefficient of lagged performance $\left(A b n P_{i}^{-}\right)$ is the parameter of interest and we are testing for the null hypothesis that there is no effect $\left(H_{0}: \delta_{1}=0\right)$ of EVA adoption on firm performance. The results suggest strong rejection of the null hypotheses for all turnovers. So the adoption of EVA has affected the operating decisions the managers take in regard of turnovers. The effects are similar for all turnovers. In these operating decision variables, none of the control variables is significant. The coefficients of the lagged performance $\left(A P_{i}^{-}\right)$in all cases are negative and highly significant. This suggests that these turnovers are significantly reduced after the adoption of EVA 
compared with matching control firms. The biggest reduction is in asset turnover (coefficient $=-0.474)$. Wallace (1997), on the other hand, finds a small positive, but significant, impact on asset turnover. The smallest, but still highly significant, impact we find is on AR turnover (coefficient=-0.199). Wallace (1997) finds a large and positive effect of EVA adoption on AR turnover. However, this effect in his study is only significant at the $10 \%$ level. The turnover reductions in inventory and AP are important and highly significant. This is in contrast to Wallace (1997) who finds no effect on these two turnovers. Overall, our results show a significant increase in the working capital cycle after adoption of EVA, implying that firm managers tend to increase profitability following adoption of an EVA based compensation plan under Wallace's assumption focusing on denominators of turnover ratios.

\section{[Table 5 about here]}

\section{Discussion and Conclusions}

In this paper we have re-examined the long-term effects of adopting economic value added (EVA) as a compensation tool. Our starting point is the seminal work of Wallace (1997) who uses a set of decisions that are expected to increase firm value and shareholder wealth. These are investing decisions (asset disposition and new investment decisions), financing decisions (share repurchase and dividends decisions) and operating decisions (asset turnover, inventory turnover, AR turnover and AP turnover). In theory, managers in adopting firms would increase asset disposition and turnover, share repurchases, dividends, inventory turnover and accounts receivable turnover, and decrease new investment and accounts payable turnover (Wallace, 1997).

Our findings are summarised in Table 6. The table shows two sets of results. The first set summarises Wallace's results. Although Wallace (1997) claims that 5 out of the 8 
performances are significant, only 3 are significant at the 5\% level (and only 1 is significant at the $1 \%$ level). More importantly, all results in Wallace (1997) have low or even negative adjusted $R^{2}$. This casts doubt on the inferential validity of his results as the regressions explain little or no variation. For example, although repurchases are found to increase after adoption with a highly significant coefficient, the $R^{2}$ suggests that only $8 \%$ of the variability of repurchases is explained by the model.

Our proposed model offers mostly different conclusions. First we note the strength of our results. All our test results indicating a strong impact of EVA adoption are significant at the $1 \%$ level and all but two results are associated with high adjusted $R^{2}$. Only one of Wallace's conclusions is consistent with our results, i.e. the new investment (although the significance level in Wallace (1997) is only $9 \%$ and matched with an adjusted $R^{2}$ of $1 \%$ ). The new investment was predicted and found to be negative by Wallace (1997), and this study is in line with that finding. An explanation of the strong and negative impact of EVA adoption on new investment might include the possibility that, when adopting EVA as a compensation plan and management tool, the criterion managers use to choose among alternative investments (projects) change, in such a way that the selected new investments have the ability to earn more than the embedded cost of debt financing. Thus, in order to increase firm value by generating more (above normal) earnings, managers will avoid over-investing, particularly in those investments that might earn less than the opportunity cost of capital and become reluctant to use free cash flows for new investments after adoption of EVA. However, we can also argue that a reduction in the new investment may lead to generate less revenue in the long term, and therefore reducing AR turnover, which is evident from our results in Table 6.

In the remaining seven variables, there is no agreement with Wallace (1997). While he finds a positive effect for dispositions, this study finds no significant effect. A possible reason for this discrepancy might be referred to the nature of the assets adopter firm owned and to the 
attractiveness of these assets to other companies. Some outside firms may believe that the adopter firm assets are in the most efficient user's hand, and may be willing to offer a price that is high enough to tempt the adopter firm to sell the asset. However, it is also possible that other firms may believe the opposite. One other possibility could be that EVA adopters are reluctant to make investments, and therefore there is no incentive for managers to dispose existing assets because disposals without replacement might damage the ability of profit generation. The result of this study is consistent with a mixed response by firms such that some adopter firms increased their dispositions while others decreased them. The insignificant results suggest that the two effects cancel out.

Wallace (1997) finds a positive effect for repurchases and no effect for dividends. We find a negative impact for both variables. A possible reason is that managers, in order to maximize their own utility, start retaining free cash flows. The retention is possibly employed as a means to insulate the firm from capital market scrutiny by avoiding extra capital needs. To avoid capital market monitoring, manager will only use the existing cash reserves that have been accumulated to finance new projects rather than paying it out to shareholders (Jensen, 1993). A possibly more interesting reason for managers to avoid paying out cash flow is the desire to maximize the firm size. ${ }^{5}$ Further, managers have more tendencies toward preventing shareholders from getting more cash to refrain them from redirecting capital to a more productive use. Moreover, firms are reluctant to increase dividend payment particularly when they are unsure about the availability of futures free cash flows and whether they can sustain the same payout ratio (dividends are sticky). Firms are also more likely to prefer to finance share repurchases from the excess cash they generate from non-recurring items rather than using the free cash flow they generate from core activities (Miller \& Rock, 1985). However, the stated purpose of the long-term incentives scheme is to align the interests of managers

\footnotetext{
${ }^{5}$ Murphy (1985) documents a positive correlation between total management compensation and firm size.
} 
with that of shareholders. To the extent that these long-term compensation plans encourage managers to develop growth opportunities, a significant fall in dividends (relative to control firms) can only be accepted if it is accompanied by a significant increase in new investments. Unfortunately, this is not the case. Both new investments and dividends/repurchases have fallen in relative terms. However, there can be a contrary argument that managers are highly motivated to reduce payouts after the adoption of EVA, because retained free cash flow would increase shareholders' equity of the firm and may lead to decrease in weighted average cost of capital (WACC). This strategy would reduce the total cost for capital and maximise managers' own interest.

The measures of turnovers (asset, inventory, accounts receivable, and accounts payable) are all highly significant and negative, suggesting potential decreases in the working capital cycle. All turnovers decline after the adoption of EVA as a performance measure. Wallace (1997) found two positive (asset turnover and accounts payable turnover) and two insignificant (inventory turnover and accounts payable turnover) effects. Thus, our results disagree with Wallace (1997) in all four cases.

We find that total asset turnover is significant and negative, which is consistent with the payout and new investment policies of EVA adopters. Lower revenue due to less new investments and higher total assets from retaining free cash flow would lead to slowing down the asset turnover ratio. If we focus on the denominator in each turnover ratio we expect a decrease in assets, inventory and AR, but an increase in AP following adoption; which helps the manager to increase operating cash flows as well as the utilisation level of net working capital. Our results provide a strong support for the expectations in AP turnover, which implies a possible increase in AP after the adoption of EVA. However, we find significant but negative signs in inventory turnover and AR turnover which are contrary to the expected 
direction. Our empirical findings imply that the results are ambiguous, which can be observed from the adjusted- $R^{2}$ statistic. Whenever effects are predicted to be ambiguous (e.g. Inventory turnover and AR turnover) the adjusted- $R^{2}$ is low. Our test results suggest that inventory may go down slower than cost of sales after the adoption of EVA. Furthermore, revenue may decrease faster than AR according to our test results. These negative results highlight that the EVA adoption provides more incentives to reduce the total cost for capital through retention of free cash flow, rather than increasing operations and maximising shareholder wealth.

\section{[Table 6 about here]}

Overall, our results show that EVA adopters relative to non-EVA adopters (a) increase the working capital cycle (b) use their assets less intensively, and (c) decrease their payouts to shareholders via a decrease in dividends and share repurchases. We only agree with Wallace (1997) on one case, namely that EVA adopters decrease their new investments. His significant and positive effect on dispositions is insignificant in our model. In the remaining six business decisions, Wallace finds three significant positive effects and three insignificant effects. All six decisions are significant but negative in our case.

While our proposed model seems more appropriate in terms of specification, the results it offers are mostly contrary to expectation. Thus, our study re-opens the debate as to whether EVA adoption leads to better or worse performance.

Our study has both empirical and practical implications. Empirically, more elaborate simulation studies may be required to establish the performance of matching and nonmatching models. Empirically, the results may be sensitive to several factors. First, it is possible that an important factor is missing from the model. The models in this study use size and leverage as firm characteristics and stock market return as a market wide control factor. Other characteristics such as firm age and industry may be influential. Second, the matching 
procedure may not produce accurate benchmarks. Following previous studies, the SIC code was used here to match treatment and control firms. This can possibly be improved by increasing the number of matching characteristics to include firm characteristics such as size, leverage and systematic risk (beta).

One obvious practical implication of this study is that tying managers with one particular performance metric may not necessarily lead to a single outcome. This is similar to the conflicting alignment-entrenchment effect of executive share-ownership discussed by Khan and Mather (2013). Another implication of the above results is that the adoption of EVA, at least in our US sample, does not generally lead to its desired effect. In particular, managers that are compensated on an EVA basis tend to maximise cash flow rather than shareholder wealth. Firms should therefore focus more on the quality of the remuneration committee (Cubinski and Windsor, 2013) as well as the characteristics of the board of directors (Gray and Nowland, in press). 


\section{References}

Balachandran, S. (2006). How Does Income Affect Investment? The Role of Prior Performance Measures. Management Science, 52(3), 383-394.

Barber, B. \& Lyon, J. (1997). Detecting Long-run Abnormal Stock Returns: The Empirical Power and Specification of Test Statistics. Journal of Financial Economics, 43(3), 341-372.

Biddle, G, Bowen, J., \& Wallace, J. (1997). Does EVA Beat Earnings? Evidence on Associations with Stock Returns and Firm Values. Journal of Accounting and Economics, 24(3), 301-336.

Christie, A. (1987). On Cross-sectional Analysis in Accounting Research. Journal of Accounting and Economics, 9(3), 231-258.

Chiwamit, P, Model, S. \& Scapens, R (2017). Regulation and adaptation of management accounting innovations: the case of Economic Value Added in Thai state-owned enterprises. Management Accounting Research, 37(December 2017), 30-48.

Cybinski, P., \& Windsor, C. (2013). Remuneration committee independence and CEO remuneration for firm financial performance. Accounting Research Journal, 26(3), 197-221.

Drucker, P.F. (1995). The Information Executives Truly Need', Harvard Business Review, January-February, 73(1), 54-62.

Gonedes, N. \& Dopuch, N. (1974). Capital Market Equilibrium, Information Production, and Selecting Accounting Techniques: Theoretical Framework and Review of Empirical Work. Journal of Accounting Research, 12(Supplement), 48-129.

Gray, S., \& Nowland, J. (in press). Director workloads, attendance and firm performance. Accounting Research Journal, https://doi.org/10.1108/ARJ-02-2016-0023

Jensen, M.C., (1993). The Modern Industrial Revolution, Exit, and the Failure of Internal Control Systems. The Journal of Finance, 48(3), 831-880.

Khan, A., \& Mather, P. (2013). The value of executive director share ownership and discretionary accruals. Accounting Research Journal, 26(1), 35-55.

Kleiman. R.T. (1999). Some New Evidence on EVA Companies'. Journal of Applied Corporate Finance, 12(2), 80-91.

Kothari, S.P. \& Zimmerman, J.L. (1995). Price and Return Model. Journal of Accounting and Economics, 20(2), 155-192.

Landsman. W. \& Magliolo, J. (1988). Cross-sectional Capital Market Research and Model Specification. The Accounting Review, 63(4), 586-604. 
Lev, B. \& Ohlson, J. (1982). Market Based Empirical Research in Accounting: a Review, Interpretations, and Extensions. Journal of Accounting Research, 20(Supplement), 249-322.

Marshall, A., (1890). Principles of Economics. London: The Macmillan Press Ltd.

McLaren, J., Appleyard, T., \& Mitchell, F. (2016). The rise and fall of management accounting systems: A case study investigation of $\mathrm{EVA}^{\mathrm{TM}}$. The British Accounting Review, 48(3), 341-358.

Miller, M.H. \& Rock, K. (1985). Dividend Policy under Asymmetric Information. The Journal of Finance, 40(4), 1031-1051.

Murphy, K.J. (1985). Corporate Performance and Managerial Remuneration: an Empirical Analysis, Journal of Accounting and Economics, 7(1), 11-42.

O’Hanlon, J. \& Peasnell, K. (1998). Wall Street's Contribution to Management Accounting: the Stern Stewart EVA ${ }^{\circledR}$ Financial Management System. Management Accounting Research, 9(4), 421-444.

Pham, P. K., Suchard, J. A., \& Zein, J. (2011). Corporate governance and alternative performance measures: evidence from Australian firms. Australian Journal of Management, 36(3), 371-386.

Riceman, S., Cahan, F.S., \& Lal, M. (2002). Do Managers Perform Better under EVA Bonus Schemes? European Accounting Review, 11(3), 537-72.

Sloan, R. G. (1996). Do Stock Prices Fully Reflect Information in Accruals and Cash Flows about Future Earnings? The Accounting Review, 71(3), 289-315.

Stern, J.M, Stewart, G.B., \& Chew, D.H. (1995). The EVA ${ }^{\circledR}$ Financial Management System. Journal of Applied Corporate Finance, 8(2), 32-46.

Stewart, G.B. (1991). The Quest for Value, New York: Harper Collins Publishers.

Stewart, G.B., (1994). EVA: Fact or Fantasy? Journal of Applied Corporate Finance, 7(2), 71-84.

Wallace, J. (1997). Adopting Residual Income-based Compensation Plans: Do You Get What You Pay for? Journal of Accounting and Economics, 24(3), 275-300.

Worthington, A.C. \& West, T. (2001). Economic Value-added: a Review of the Theoretical and Empirical Literature. Asian Review of Accounting, 9(1), 67-86.

Worthington, A. C. \& West, T. (2004). Australian evidence concerning the information content of economic value-added. Australian Journal of Management, 29(2), 201-223. 


\section{Appendix}

Table A1. EVA Adopting Companies 1987-2001(USA)

\begin{tabular}{|c|c|c|c|c|}
\hline No. & Sample Company & $\begin{array}{c}\text { Adoption } \\
\text { Year }\end{array}$ & Control Company & SIC Code \\
\hline 1 & COCA COLA & 1987 & PEPSICO INC & 2080 \\
\hline 2 & CSX CORPORATION & 1988 & SANTA FE FINANCIAL CORP & 6711 \\
\hline 3 & CILCORP & 1989 & ALLETE INC & 4931 \\
\hline 4 & CRANE CO & 1990 & WHITTAKER CORP & $3490 / 3494$ \\
\hline 5 & BRIGGS \& STRATTON & 1990 & STEWART \& STEVENSON SVCS INC & $3510 / 3519$ \\
\hline 6 & QUAKER OATS & 1991 & RALSTON PURINA CO & $2040 / 2043$ \\
\hline 7 & BALL CORP & 1992 & CROWN HOLDINGS INC & 3221 \\
\hline 8 & WHIRLPOOL CORP & 1992 & AKTIEBOLAGET ELECTROLUX & 3630 \\
\hline 9 & AT\&T & 1992 & G T E CORP & 4813 \\
\hline 10 & Scherer, R.P. & 1992 & FOREST LABS INC & 2834 \\
\hline 11 & WELLMAN & 1993 & ASHLAND INC NEW & 2824 \\
\hline 12 & Grainger, W.W. & 1993 & WAXMAN INDUSTRIES INC & 5063 \\
\hline 13 & MANITOWOC CO & 1993 & ASTEC INDUSTRIES INC & 3531 \\
\hline 14 & Digital Equipment Corp. & 1993 & APPLE INC & 3573 \\
\hline 15 & FURON CORP. & 1993 & WYNNS INTERNATIONAL INC & 3079 \\
\hline 16 & Harnischfeger Ind. Inc. & 1993 & APPLIED MATERIALS INC & 3536 \\
\hline 17 & Hewlett Packard Co. & 1993 & HITACHI LIMITED & 3571 \\
\hline 18 & Ruby Tuesday Inc. & 1993 & $\begin{array}{l}\text { WORLDWIDE RESTAURANT } \\
\text { CNCPTS INC }\end{array}$ & 5812 \\
\hline 19 & Smith International Inc. & 1993 & CABOT CORP & 3533 \\
\hline 20 & Transamerica Corp. & 1993 & LOEWS CORP & 6711 \\
\hline 21 & ACXIOM CORP & 1994 & MCGRAW HILL COS INC & 7370 \\
\hline 22 & BOISE CASCADE CORP & 1994 & BT OFFICE PRODUCTS INTL INC & 2421 \\
\hline 23 & FLEMING COMPANIES INC & 1994 & NASH FINCH COMPANY & 5141 \\
\hline 24 & GEORGIAPACIFIC GROUP & 1994 & WEYERHAEUSER CO & 2435 \\
\hline 25 & LILLY (ELI) \& CO & 1994 & WYETH & 2834 \\
\hline 26 & SPRINT FON GROUP & 1994 & CENTEL CORP & 4813 \\
\hline 27 & CENTURA BANKS INC & 1994 & AMERICAN FLETCHER CORP & 6036 \\
\hline 28 & Core Industries Inc. & 1994 & WHITTAKER CORP & 3429 \\
\hline 29 & Deere \& Co. & 1994 & KUBOTA CORP & 3523 \\
\hline 30 & Eastman Chemical Co. & 1994 & ROHM \& HAAS CO & 3861 \\
\hline
\end{tabular}


Table A1 continued.

\begin{tabular}{|c|c|c|c|c|}
\hline No. & Sample Company & $\begin{array}{c}\text { Adoption } \\
\text { Year }\end{array}$ & Control Company & SIC Code \\
\hline 31 & Gencorp Inc. & 1994 & LOCKHEED MARTIN CORP & 3011 \\
\hline 32 & Incstar Corp. & 1994 & A M A G PHARMACEUTICALS INC & 2830 \\
\hline 33 & Insteel Industries & 1994 & NATIONAL STANDARD CO & 3310 \\
\hline 34 & Ohio Edison Co. & 1994 & NORTHEAST UTILITIES & 4911 \\
\hline 35 & Reynolds Metals Co. & 1994 & KAISERTECH LTD & 3353 \\
\hline 36 & Tenneco Inc. & 1994 & CHAMPION PARTS INC & 3714 \\
\hline 37 & Wallace Computer Services & 1994 & MOORE WALLACE INC & 2761 \\
\hline 38 & ZOLTEK Cos. Inc. & 1994 & WOODWARD INC & 3620 \\
\hline 39 & ARMSTRONG HOLDINGS INC & 1995 & NEWELL RUBBERMAID INC & 2511 \\
\hline 40 & BARD (C.R.) & 1995 & TELEFLEX INC & 5086 \\
\hline 41 & PERKINELMER INC & 1995 & BIO RAD LABORATORIES INC & 3823 \\
\hline 42 & SPX CORP & 1995 & GIDDINGS \& LEWIS INC WIS & 3540 \\
\hline 43 & American Precision Ind. & 1995 & FRANKLIN ELECTRIC INC & 3443 \\
\hline 44 & Armstrong World Industries Inc. & 1995 & E G \& G INC (VISKASE COMPANIES) & 2511 \\
\hline 45 & Beckman Instruments Inc. & 1995 & PERKINELMER INC & 5311 \\
\hline 46 & Emerson Electric Co. & 1995 & PANASONIC CORP & $3621 / 3823$ \\
\hline 47 & IPALCO Enterprises Inc. & 1995 & Tucson/U N S ENERGY CORP & 4911 \\
\hline 48 & KAISER ALIUMINUM Corp. & 1995 & MAXXAM INC & 3334 \\
\hline 49 & Knight-Ridder Inc. & 1995 & NEW YORK TIMES CO & 2711 \\
\hline 50 & New Jersey Resources & 1995 & ATMOS ENERGY CORP & 4924 \\
\hline 51 & Sequent Computer & 1995 & STRATUS COMPUTER INC & 3570 \\
\hline 52 & ADC TELECOMMUNICATIONS INC & 1996 & TELLABS INC & 3679 \\
\hline 53 & BAUSCH \& LOMB INC & 1996 & CHIRON CORP & 3861 \\
\hline 54 & BECTON DICKINSON \& CO & 1996 & BARD C R INC & 3841 \\
\hline 55 & DONNELLEY (R R) \& SONS CO & 1996 & BOWNE \& CO INC & 3229 \\
\hline 56 & GUIDANT CORP & 1996 & MEDTRONIC INC & 3841 \\
\hline 57 & KANSAS CITY POWER \& LIGHT & 1996 & C M P GROUP INC & 4911 \\
\hline 58 & OLIN CORP & 1996 & F M C CORP & 2810 \\
\hline 59 & SILICON VY BANCSHARES & 1996 & AMSOUTH BANCORPORATION & $6022 / 6710$ \\
\hline 60 & TUPPERWARE CORP & 1996 & ENVIRODYNE INDUSTRIES INC & 3089 \\
\hline
\end{tabular}




\begin{tabular}{|c|c|c|c|c|}
\hline No. & Sample Company & $\begin{array}{l}\text { Adoption } \\
\text { Year }\end{array}$ & Control Company & SIC Code \\
\hline 61 & MILLER HERMAN & 1996 & H N I CORP & 2531 \\
\hline 62 & Cincinnati Milacron & 1996 & KENNAMETAL INC & 3541 \\
\hline 63 & HACH Co. & 1996 & COHERENT INC & 3820 \\
\hline 64 & KLLM Transport Services & 1996 & MATLACK SYSTEMS INC & 4210 \\
\hline 65 & NEW ENGLAND BUSINESS SERVICES & 1996 & ENNIS INC & 2761 \\
\hline 66 & Quaker State & 1996 & TESORO CORP & 2911 \\
\hline 67 & STRATTEC SECURITY CORP & 1996 & F M C CORP & 8740 \\
\hline 68 & TEKTRONIX & 1996 & SNAP ON INC & 3825 \\
\hline 69 & CDI CORP & 1997 & ROBERT HALF INTL INC & 3269 \\
\hline 70 & GC COMPANIES INC & 1997 & MARCUS CORP & 7830 \\
\hline 71 & JOHNSON OUTDOORS INC & 1997 & ELECTRO SCIENTIFIC INDS INC & 3940 \\
\hline 72 & MILLENNIUM CHEMICALS INC & 1997 & BIG THREE INDS INC & 2813 \\
\hline 73 & PHARMACIA CORP & 1997 & BAUSCH \& LOMB INC & 2823 \\
\hline 74 & RYDER SYSTEM INC & 1997 & ROLLINS TRUCK LEASING CORP & 6159 \\
\hline 75 & TENET HEALTHCARE CORP & 1997 & UNIVERSAL HEALTH SERVICES INC & 8062 \\
\hline 76 & WEBSTER FINL CRP WATERBURY & 1997 & AMSOUTH BANCORPORATION & 6035 \\
\hline 77 & FEDERALMOGUL CORP & 1998 & DANA HOLDING CORP & 3562 \\
\hline 78 & MATERIAL SCIENCES CORP & 1998 & SHAW GROUP INC & 3470 \\
\hline 79 & MONTANA POWER CO & 1998 & C H ENERGY GROUP INC & 4911 \\
\hline 80 & PENNEY (J C) CO & 1998 & DILLARDS INC & 5311 \\
\hline 81 & STANDARD MOTOR PRODS & 1998 & HARBINGER GROUP INC & 3694 \\
\hline 82 & BRADLEY PHARMACEUTICALS & 1998 & BALCHEM CORP & $2830 / 5120$ \\
\hline 83 & BEST BUY CO INC & 1998 & RADIOSHACK CORP & 5732 \\
\hline 84 & INTERNATIONAL MULTIFOODS & 1999 & RALSTON PURINA CO & 2041 \\
\hline 85 & TOYS R US INC & 1999 & MICHAELS STORES INC & 6711 \\
\hline 86 & GENESCO & 1999 & FOOT LOCKER INC & 2341 \\
\hline 87 & MOLSON COORS & 1999 & ANHEUSER BUSCH COS INC & 2082 \\
\hline 88 & SCHNITZER STEEL & 2000 & ENVIROSOURCE INC & 3310 \\
\hline 89 & HARSCO & 2001 & DYNAMIC MATERIALS CORP & 3446 \\
\hline
\end{tabular}

Source: Wallace (1997), Kleiman (1999), Stern Stewart \& Co. brochure, Lexis-Nexis, Proxy Statement and 10-Q report and Wall Street Journal. 


\section{LIST OF TABLES}

\section{Table 1. EVA Adoption over Time}

\begin{tabular}{cccc}
\hline Year & $\begin{array}{c}\text { Number } \\
\text { of Adopter }\end{array}$ & $\begin{array}{c}\text { Percent } \\
\text { of sample }\end{array}$ & $\begin{array}{c}\text { Cumulative } \\
\text { percent of sample }\end{array}$ \\
\hline 1987 & 1 & 1.12 & 1.12 \\
1988 & 1 & 1.12 & 2.25 \\
1989 & 1 & 1.12 & 3.37 \\
1990 & 2 & 2.25 & 5.62 \\
1991 & 1 & 1.12 & 6.74 \\
1992 & 4 & 4.49 & 11.24 \\
1993 & 10 & 11.24 & 22.47 \\
1994 & 18 & 20.22 & 42.70 \\
1995 & 13 & 14.61 & 57.30 \\
1996 & 17 & 19.10 & 76.40 \\
1997 & 8 & 8.99 & 85.39 \\
1998 & 7 & 7.87 & 93.26 \\
1999 & 4 & 4.49 & 97.75 \\
2000 & 1 & 1.12 & 98.88 \\
2001 & 1 & 1.12 & 100.00 \\
\hline Total & 89 & $100 \%$ & $100 \%$ \\
\hline
\end{tabular}


Table 2. Selected descriptive statistics on the dependent and independent variables

\begin{tabular}{|l|r|r|r|r|r|r|}
\hline \multirow{2}{*}{ Variables } & \multicolumn{3}{|c|}{ Adopter (Treatment) Firms } & \multicolumn{3}{c|}{ Control Firms } \\
\cline { 2 - 7 } & $\mathrm{N}$ & \multicolumn{1}{c|}{ Mean } & $\begin{array}{c}\text { Std. } \\
\text { Deviation }\end{array}$ & $\mathrm{N}$ & Mean & $\begin{array}{c}\text { Std. } \\
\text { Deviation }\end{array}$ \\
\hline Disposition* & 1933 & 26.191 & 83.678 & 2083 & 21.596 & 81.719 \\
New Investment* & 3411 & 285.998 & 698.578 & 3453 & 251.002 & 632.354 \\
Repurchases per share & 3464 & 0.477 & 1.204 & 3585 & 0.453 & 1.268 \\
Dividends per share & 3441 & 0.89 & 1.061 & 3573 & 0.857 & 1.466 \\
Asset Turnover & 3331 & 1.298 & 0.808 & 3555 & 1.199 & 0.763 \\
Inventory Turnover & 3206 & 9.148 & 13.164 & 3417 & 9.784 & 14.041 \\
AR Turnover & 3245 & 10.022 & 12.165 & 3425 & 9.895 & 14.035 \\
AP Turnover & 2886 & 11.551 & 7.483 & 3186 & 11.119 & 6.729 \\
Debt* & 3423 & 1930.364 & 5704.894 & 3628 & 1846.283 & 5582.607 \\
\hline
\end{tabular}

* These variables are in $\$$ million. Statistics are based on annual accounting data available from 1960 to 2012. Sample sizes represent firm-years. Disposition is the sale of plant, property and equipment. New investment is acquisitions plus capital expenditures. Purchases per share are (\$) purchases of common stock divided by Common Shares Outstanding. Dividends are dividends (in \$) available to common shareholders divided by Common Shares Outstanding. Assets turnover is revenue divided by average total assets. Inventory turnover is calculated as cost of goods sold divided by average inventory. Accounts Receivable (AR) Turnover is defined as revenue divided by average accounts receivable. Accounts Payable (AP) Turnover is the cost of goods sold divided by average accounts payable, and Debt is the company's total debt. All dependent variables are winsorised at the $99 \%$ percentile to remove potential outlier effect. 
Table 3. Investing Decisions

\begin{tabular}{|c|c|c|c|c|c|}
\hline \multirow[b]{2}{*}{$A b n P_{i}^{+}-A b n P_{i}^{-}$} & \multicolumn{5}{|c|}{ Independent Variables } \\
\hline & Constant & $A b n P_{i}^{-}$ & $A b n T A_{i}^{+}$ & $A b n D e b t_{i}^{+}$ & $A D J-R^{2}$ \\
\hline \multicolumn{6}{|l|}{ Dispositions } \\
\hline Coefficient & -6.154 & -0.009 & 0.003 & -0.024 & \multirow{3}{*}{$34.01 \%$} \\
\hline$t$-statistics & -0.878 & -0.088 & 2.988 & -4.653 & \\
\hline p-value & 0.385 & 0.929 & 0.005 & 0.000 & \\
\hline \multicolumn{6}{|l|}{ New investment } \\
\hline Coefficient & 43.192 & -0.679 & 0.017 & 0.055 & \multirow{3}{*}{$51.04 \%$} \\
\hline$t$-statistics & 2.112 & -8.177 & 4.375 & 3.935 & \\
\hline p-value & 0.038 & 0.000 & 0.000 & 0.000 & \\
\hline
\end{tabular}


1

2

3

4

5

6

7

8

9

10

11

12

13

14

15

16

17

18

19

20

21

22

23

24

25

26

27

28

29

30

31

32

33

34

35

36

37

38

39

40

41

42

43

44

45

46

47

48

49

50

51

52

53

54

55

56

57

Table 4. Financing Decisions

\begin{tabular}{|c|c|c|c|c|c|}
\hline \multirow[b]{2}{*}{$A b n P_{i}^{+}-A b n P_{i}^{-}$} & \multicolumn{5}{|c|}{ Independent Variables } \\
\hline & Constant & $A b n P_{i}^{-}$ & $A b n T A_{i}^{+}$ & $A b n D e b t_{i}^{+}$ & $A D J-R^{2}$ \\
\hline \multicolumn{6}{|c|}{ Share Repurchases } \\
\hline Coefficient & 0.111 & -0.591 & -0.000 & 0.000 & \multirow{3}{*}{$20.12 \%$} \\
\hline$t$-statistics & 0.925 & -4.635 & -0.174 & 0.368 & \\
\hline p-value & 0.358 & 0.000 & 0.862 & 0.714 & \\
\hline \multicolumn{6}{|l|}{ Dividends } \\
\hline Coefficient & 0.037 & -0.568 & -0.000 & 0.000 & \multirow{3}{*}{$75.00 \%$} \\
\hline t-statistics & 0.705 & -14.854 & -0.363 & 0.475 & \\
\hline$p$-value & 0.483 & 0.000 & 0.717 & 0.636 & \\
\hline
\end{tabular}


Table 5. Operating Decisions (New Model)

\begin{tabular}{|c|c|c|c|c|c|}
\hline \multirow[b]{2}{*}{$A b n P_{i}^{+}-A b n P_{i}^{-}$} & \multicolumn{5}{|c|}{ Independent Variables } \\
\hline & Constant & $A b n P_{i}^{-}$ & $A b n T A_{i}^{+}$ & $A b n D e b t_{i}^{+}$ & $A D J-R^{2}$ \\
\hline \multicolumn{6}{|l|}{ Asset Turnover } \\
\hline Coefficient & 0.046 & -0.474 & -0.000 & -0.000 & \multirow{3}{*}{$52.23 \%$} \\
\hline t-statistics & 1.232 & -9.139 & -0.054 & -0.062 & \\
\hline p-value & 0.222 & 0.000 & 0.957 & 0.537 & \\
\hline \multicolumn{6}{|c|}{ Inventory Turnover } \\
\hline Coefficient & 0.992 & -0.450 & -0.0002 & -0.0001 & \multirow{3}{*}{$11.66 \%$} \\
\hline$t$-statistics & 0.691 & -2.927 & -1.115 & -0.0727 & \\
\hline$p$-value & 0.491 & 0.004 & 0.268 & 0.942 & \\
\hline \multicolumn{6}{|l|}{ AR Turnover } \\
\hline Coefficient & 0.005 & -0.199 & -0.0000 & 0.0005 & \multirow{3}{*}{$5.30 \%$} \\
\hline t-statistics & -0.006 & -2.412 & -0.351 & 0.893 & \\
\hline$p$-value & 0.995 & 0.018 & 0.726 & 0.374 & \\
\hline \multicolumn{6}{|l|}{ AP Turnover } \\
\hline Coefficient & -1.073 & -0.453 & -0.00002 & 0.0001 & \multirow{3}{*}{$29.34 \%$} \\
\hline$t$-statistics & -1.582 & -5.687 & -0.319 & 0.220 & \\
\hline p-value & 0.118 & 0.000 & 0.750 & 0.826 & \\
\hline
\end{tabular}


2

Table 6. Summary of Results

\begin{tabular}{|l|c|c|}
\hline $\begin{array}{l}\text { Variable } \\
\text { (Predicted Sign) }\end{array}$ & $\begin{array}{c}\text { Wallace Model } \\
\left(\mathrm{p} \text {-val, ADJ- R }{ }^{2}\right)\end{array}$ & $\begin{array}{c}\text { Our Model } \\
\left(\mathrm{p}-\mathrm{val}, \mathrm{ADJ}-\mathrm{R}^{2}\right)\end{array}$ \\
\hline Dispositions (+) & Positive $(0.02,0.09)$ & $\mathrm{nr}(0.93,0.34)$ \\
\hline New investment (-) & Negative $(0.09,0.01)$ & Negative $(0.00,0.51)$ \\
\hline Repurchases (+) & Positive $(0.00,0.08)$ & Negative $(0.00,0.20)$ \\
\hline Dividends (+) & $\operatorname{Nr}(0.26,-0.00)$ & Negative $(0.00,0.75)$ \\
\hline Asset Turnover (+) & Positive $(0.05,0.11)$ & Negative $(0.00,0.52)$ \\
\hline Inventory Turnover (+) & $\operatorname{Nr}(0.26,-0.03)$ & Negative $(0.00,0.11)$ \\
\hline AR Turnover (+) & Positive $(0.08,-0.01)$ & Negative $(0.02,0.05)$ \\
\hline AP Turnover (-) & $\operatorname{Nr}(0.38,-0.04)$ & Negative $(0.00,0.29)$ \\
\hline
\end{tabular}

(nr) means no significant relationship. 